Nafiz Zaman Shuva

Western University, London, ON, Canada

Paulette Rothbauer

Western University, London, ON, Canada

CAIS 2020

\title{
"You made a great mistake...you left the [your] job and moved to Canada": A study on the information experiences of Bangladeshi immigrants in Canada
}

\begin{abstract}
Résumé:
This paper reports on key findings from a recently completed doctoral study into the transitional information behaviour of Bangladeshi immigrants to Canada. The study uses a mixed method approach including semi-structured interviews $(n=60)$ and surveys $(n=205)$ with Bangladeshi immigrants who arrived in Canada between the years of 1971 and 2017. We discuss the information experience of participants in terms of their personal networks, information sharing fear, and information intelligence.
\end{abstract}

\section{Introduction and Study Approach}

Canada is one of the top ten destination countries for international migrants (United Nations, Department of Economic and Social Affairs, Population Division, 2019), and is the second most desired destination for migrants according to Gallup World Poll, 2015-2017 (Esipova, Pugliese \& Ray 2018, December 10). Canada actively welcomes immigrants from all over the world. The Government of Canada aims to recruit more than one million immigrants by 2021, with the majority classed as skilled immigrants (Immigration, Refugees and Citizenship Canada (IRCC), 2018). Several studies report the mismatch between immigrants' expectations about life in Canada and their actual experiences (e.g., Khan \& Watson 2005; Simich, Hamilton \& Baya 2006; Zaman 2010). At times, this results in anxiety, frustration, and despair, which in turn, affect settlement and integration (George \& Tsang 2000; Simich et al. 2006).

Immigrants need information before and after their arrival to make informed decisions about their move and for their satisfactory settlement into a new society. Relevant, authoritative information encountered at the point of need can aid in newcomer's settlement, which can in turn, support social inclusion (Caidi, Allard \& Quirke 2010; Caidi \& Allard 2005; Esses \& Medianu 2012). In order to satisfy a multitude of settlement information needs, immigrants consult various information sources to gather information about their host country and to orient themselves with the new systems and culture.

In this paper, we present the results of an exploratory, mixed-method study on the information experiences of Bangladeshi immigrants to Canada. Findings are based on data collected from semistructured interviews conducted from May 2017 to February 2018 with 60 participants (21 face-to- 
face; 37 by telephone; and two via Skype), and from 205 survey responses from December 2017 to March 2018. We also feature two main theoretical concepts to emerge from the analysis of the interview data - "information sharing fear" and "information intelligence".

We first present the information experiences of Bangladeshi immigrants within their personal networks, including friends, family, and ethnic community people. By information experience, we mean Bangladeshi immigrants' experiences with active and passive interaction with information resources, information sharing, information use, and other information processes in the context of their settlement lives in Canada. We are informed by the work of Bruce, Davis, Hughes, Partridge \& Stoodley (2014) who conceptualize information experience as "the way in which people experience or derive meaning from the way in which they engage with information and their lived worlds as they go about their daily life and work" (p.6).

\section{Information Experiences and Personal Information Networks}

The interview participants did not always actively seek information from their interpersonal networks, but in ways that recall Fisher's concept of information grounds (2005), they were often indirectly informed through experiences at various social and community gatherings and events after arrival in Canada. However, findings show that participants sometimes received discouraging, unhelpful, or wrong information from their personal networks. The multiple dimensions of the information experiences of the study participants show the many consequences for their settlement lives. For example, participants receiving positive information about life in Canada before arrival were not prepared to face the initial challenges especially regarding employment and many were bitterly disappointed with their settlement experience. In contrast, participants who received negative information about prospects of professional employment perceived finding a professional job nearly impossible. Many of these participants tempered their expectations and were prepared for they considered "survival jobs" after arrival despite their skills, credentials, education, and potential. Interview participants also described how their information experiences with Bangladeshi community people were sometimes demotivating for their employment-related settlement after arrival.

\section{Information Sharing Fear}

For some participants settlement was particularly impacted by the concept of "information sharing fear" that emerged from the interviews. Some Bangladeshi immigrants described how sharing information about the reality of what life in Canada was really like for them (including its difficulties) might result in troubled relationship dynamics with family and friends interested in immigrating to Canada. Information sharing fear relates to concerns that sharing information about the challenges faced by newcomers could be considered by potential immigrants as a kind of active "discouragement." Participants described being sensitive to charges of envy or jealousy when they shared information related to challenges newcomers face, as friends and family see them as trying to prevent competition for social status. Participants also described this kind of information sharing in terms of fear and loss - fear of losing their connections with their friends and family back home interested in immigrating to Canada. We discuss the implications of this finding for settlement information behaviour. 


\section{Information Intelligence}

Finally, we discuss the concept of "information intelligence" that emerged in this study. In studies of access to information immigrants are often conceived of as a vulnerable population (Adekanmbi 2019; Caidi \& Allard 2005; Caidi, Allard, \& Quirke 2010). It is evident in this study that not all Bangladeshi immigrants are vulnerable. Some recent immigrants have informational and social skills and competencies that allow them to be comfortable, efficient, and sometimes effective, at gathering information by themselves from multiple information sources. Information intelligent immigrants are proactive information seekers who utilize all possible information avenues to become informed about life before arrival and importantly, they continue their efforts after arrival to gather a complete perspective of settlement lives in Canadian contexts. The primary quality of information intelligence is an understanding of the central importance of information in solving everyday life problems, preparing to tackle settlement challenges, and preparing to achieve success in life. Such information seekers gather comprehensive information about life in Canada and take proactive information initiatives to understand how various systems work in Canada. Among other things, this kind of information seeking allows them to construct reasonable post-arrival expectations. The information they collect is not always based on their immediate information needs; rather, they predict the information that might be useful in the future to tackle settlement challenges and that support informed decisions about their move to Canada.

\section{Significance of the study in LIS and interdisciplinary contexts:}

The concepts of information experience, information sharing fear, and information intelligence have many theoretical and practical implications for policy and research. First, this study provides insights into the complicated culturally situated information experiences of Bangladeshi immigrants consulting unofficial information sources such as friends and family, including members of their broader ethnic communities. Although several studies (such as George and Chaze 2009; Teixeira \& Drolet 2018; Telegdi 2006) report immigrants benefit from their friends and family networks in the host country, this study highlights a mixed information experience among Bangladeshi immigrants. The study participants did not always receive useful information and guidance but rather received information (before and after arrival) that actually disappointed and misguided them. The study findings encourage researchers in various disciplines, including migrational studies, to go deeper into newcomers' experiences with their social networks using an informational lens to examine the information newcomers receive from their social networks and its effects on their post-arrival settlement in a new country.

Secondly, this paper also puts forward a new concept, that of "information sharing fear" among some Bangladeshi immigrants. As evident in our study, due to information sharing fear, newcomers consulting their friends and family may not receive an accurate picture of Canadian life, and therefore, may not be able to make an informed decision nor to mentally prepare themselves to face initial settlement challenges after arrival. These findings suggest that identifying factors that discourage people from sharing information are also important to understand the information experience. In what contexts do people share (or not share) information? What factors affect people's attitudes and orientation to sharing information? By identifying information sharing fear in different contexts (such as health, immigration) and the factors affecting people's information sharing behaviour would help policymakers design appropriate policy to encompass differing attitudes toward information and informing others. 
Finally, the findings of this study also contribute to the small number of studies (such as Khoir 2016; Abdi, Partridge, Bruce \& Watson 2019) that position newcomers as comfortable and proficient information seekers. Despite the number of studies that explore the vulnerabilities and challenges of immigrants, the findings of this study show many recent immigrants are not always vulnerable in terms of information gathering and they utilize many information sources including online sources such as forums, blogs, and websites to satisfy their information needs. Immigrants who possess an "information intelligence" are information experts who gather information in pre- and post-arrival contexts. The findings related to information intelligence are important contributions as they encourage researchers working on information literacy skills to identify other competencies that new generations of information seekers may have rather than solely focusing on information literacy skills. The theoretical contribution of information intelligence in our study also suggests directions for libraries of all types offering information literacy training to international students, immigrants, newcomers, and other migrants to revise traditional information literacy curriculum to help users understand the importance of information in more holistic, everyday life contexts.

\section{Reference List:}

Abdi, E.S., Partridge, H., Bruce, C., \& Watson, J. (2019). Skilled immigrants: A resettlement information literacy framework. Journal of Documentation, 75(4), 892-908. https://doi.org/10.1108/JD-02-20190034

Adekanmbi, O. F. (2019). Investigating and proffering solutions to the information seeking behaviour of immigrants in the United Kingdom. Library Philosophy and Practice, 1-11. Retrieved from https://digitalcommons.unl.edu/cgi/viewcontent.cgi?article=5751\&context=libphilprac

Allard, D. (2015). Living "here" and "there": Exploring the transnational information practices of newcomers from the Philippines to Winnipeg (Doctoral dissertation). Retrieved from https://tspace.library.utoronto.ca/bitstream/1807/70865/1/Allard_Danielle_201511_PhD_thesis.pdf

Bruce, C., Davis, K., Hughes, H., Partridge, H., \& Stoodley, I. (2014). Information experience: Contemporary perspectives. In Information experience: Approaches to theory and practice (pp. 3-15). Emerald Group Publishing Limited.

Caidi, N., \& Allard, D. (2005). Social inclusion of newcomers to Canada: An information problem?. Library \& Information Science Research, 27(3), 302-324. https://doi.org/10.1016/j.lisr.2005.04.003

Caidi, N., Allard, D., \& Quirke, L. (2010). Information practices of immigrants. Annual review of information science and technology, 44(1), 491-531. https://doi.org/10.1002/aris.2010.1440440118

Esipova, N., Pugliese, A., \& Ray, J. (2018, December 10). More than 750 million worldwide would migrate If they could. Gallup News, Retrieved from https://news.gallup.com/poll/245255/750-millionworldwide-migrate.aspx

Esses, V. M., \& Medianu, S. (2012). Integration barriers and information as a solution: Report based on literature covering 2005-2011 inclusive. Retrieved from

http://welcomingcommunities.net/files/2013/01/Integration-Barriers-and-Infomation-as-a-Solution.pdf 
Fisher, K.E. (2005). Information grounds. In K.E. Fisher, S. Erdelez \& L. McKechnie (Eds.), Theories of information behavior (pp. 185-190). Medford, NJ: Information Today, Inc. (ASIST Monograph Series).

George, U., \& Chaze, F. (2009). "Tell me what I need to know": South Asian women, social capital and settlement. Journal of International Migration and Integration/Revue de l'integration et de la migration internationale, 10(3), 265-282. https://doi.org/10.1007/s12134-009-0102-3

George, U., \& Tsang, A. K. T. (2000). Newcomers to Canada from former Yugoslavia: Settlement issues. International Social Work, 43(3), 381-393. https://doi.org/10.1177/002087280004300309

Immigration, Refugees and Citizenship Canada (IRCC). (2018). 2018 Annual Report to Parliament on Immigration. Retrieved from https://www.canada.ca/content/dam/ircc/migration/ircc/english/pdf/pub/annual-report-2018.pdf

Khoir, S. (2016). An information behaviour perspective into Asian immigrants' settlement in urban South Australia: Investigating their everyday life information seeking and the value of public library services (Doctoral dissertation). Retrieved from https://ap01a.alma.exlibrisgroup.com/view/delivery/61USOUTHAUS_INST/12145033070001831

Khan, S., \& Watson, J. C. (2005). The Canadian immigration experiences of Pakistani women: Dreams confront reality. Counselling Psychology Quarterly, 18(4), 307-317. https://doi.org/10.1080/09515070500386026

Simich, L., Hamilton, H., \& Baya, B. K. (2006). Mental distress, economic hardship and expectations of life in Canada among Sudanese newcomers. Transcultural Psychiatry, 43(3), 418-444. https://doi.org/10.1177/1363461506066985

Teixeira, C., \& Drolet, J. L. (2018). Settlement and housing experiences of recent immigrants in smalland mid-sized cities in the interior of British Columbia (Canada). Journal of Housing and the Built Environment, 33(1), 19-43. https://doi.org/10.1007/s10901-017-9550-9

Telegdi, A. (2006). Family Reunification: The key to successful integration. Canadian Issues, 2006(Spring), 94-96.

United Nations, Department of Economic and Social Affairs, Population Division (2019). International Migrant Stock 2019 (United Nations database, POP/DB/MIG/Stock/Rev.2019). Retrieved from https://www.un.org/en/development/desa/population/migration/publications/populationfacts/docs/Migr ationStock2019_PopFacts_2019-04.pdf

Zaman, H. (2010). Pakistani skilled/educated immigrant women in Canada: An exploratory study. Pakistan Journal of Women's Studies, 17(2), 1-23. 